\title{
Aged-Related Differences in the Predictability of Verb-Thematic Roles: An Eye-Tracking Study
}

\author{
Sang Heum Hwang, ${ }^{\mathrm{a}}$, Jee Eun Sung \\ ${ }^{a}$ Department of Communication Disorders, Graduate School, Ewha Womans University, Seoul, Korea \\ ${ }^{b}$ Department of Communication Disorders, Ewha Womans University, Seoul, Korea
}

Correspondence: Jee Eun Sung, PhD

Department of Communication Disorders, Ewha Womans University, 52 Ewhayeodae-gil, Seodaemun-gu, Seoul 03760, Korea

Tel: +82-2-3277-2208

Fax: +82-2-3277-2122

E-mail: jeesung@ewha.ac.kr

Received: April 5, 2019

Revised: May 4, 2019

Accepted: May 4, 2019

This work was supported by the Ministry of Education of the Republic of Korea and the National Research Foundation of Korea (No. NRF2017S1A2A2038375).

\begin{abstract}
Objectives: The goal of the study was to identify the age-related declines in verb-mediated prediction in Korean using Subject-Verb-Object (SVO) word order via eye-tracking. Therefore, this study compares the predictive processing ability of the group (younger and older) according to the semantic degree of prediction (high and low) of the verb based on the functional associations of verb-noun. Methods: The participants were 20 young adults aged 20-39 (age 23.84 \pm 2.56 years) and 20 older adults aged 60-79 (age, 66.00 \pm 2.70 years). Experiments were conducted on a computer equipped with an eye-tracker and participants selected a picture while listening to a voice stimulus. The task had two conditions on the degree of prediction. Results: This study examined the difference between groups according to the degree of semantic prediction (high and low) of the verb. The results showed that the elderly and younger age group exhibited a significant difference on predicted response times and the proportion of target fixations. Conclusion: Real-time processing has shown that older age groups have a declined ability to use verb information. Younger people are faster in using verb information and are more efficient in dealing with semantically strong verbs that constrain semantics. The results show that the ability to use the semantic network of the verb to predict noun words decrease with age.
\end{abstract}

Keywords: Eye-tracking, Aging, Verb-noun association, Verb-mediated prediction, Thematic role
노화에 의한 언어처리능력 및 기억력의 감퇴는 국내외를 막론하 고 관심을 갖고 연구하는 분야이다. 의학기술의 발달과 의식주의 발달로 인해 수명은 연장되었고, 전 세계적으로 평균 수명이 점점 증가하고 있기 때문이다. 많은 선행연구는 노화에 의해 문장의 실 시간 처리 감퇴가 일어난다는 주장에 동의한다. 특히 Cohen (1979) 은 연령의 효과를 조사한 결과 노년층은 추론, 예측을 하거나 예외 를 탐지하는 데 어려움이 있음을 강조했다. 예측력은 언어 이해에 있어서 중요한 역할을 한다. 의사소통은 빠르게 진행되고, 이로 인 해 빠르고 효율적인 언어처리능력이 중요시된다. 의사소통 과정 중 에 다음에 나올 단어에 대한 빠른 예측은 빠르고 효율적인 대화로 연결되고, 청자들은 언어적인 정보와 비언어적인 정보를 미리 예측 하며 소통한다.

Altmann과 Kamide (1999)는 동사로부터 나온 선택적인 정보가
앞으로 나올 내용 및 대상을 예측하는 데 사용됨을 보고하였다. 이 외 많은 연구들이 시선추적 실험을 통해 의사소통을 할 때 동사로 부터 나온 정보를 가지고 뒤에 나올 대상(objects)을 미리 예측하고, 목표 대상(target objects)으로의 시선 움직임(eye movements)을 보 인다는 것을 입증했다(Hintz, Meyer, \& Huettig, 2017). 다음에 나 올 대상을 예측하게 하는 다양한 요소 중 동사와 명사의 의미적 연 관성이 이후에 나올 명사구 의미역에 대한 예측원으로서 가장 중 요한 역할을 한다고 주장한 연구가 있다(Hintz et al., 2017). Hintz 등(2017)은 예측 처리 실험을 통해 실험 참가자들은 동사를 듣고 난 이후, 목표 명사(target nouns)가 언급되기 1초 전에 이미 목표 명사를 보는 경향을 보였고, 이를 통해 동사를 들었을 때 다음에 나올 명사에 대한 예측과 문장 이해가 가능했음을 알 수 있다고 주 장했다. 예측 능력과 빠른 문장처리는 언어처리능력의 근간이 되기 
때문에 노년층의 언어처리에 대한 연구에서 예측과 관련한 논의는 필수적이다.

문장처리 및 예측 과정에서 동사의 역할은 중요하다. 동사는 서 술어의 기능을 하는 품사이며, 문장을 구성하는 데 없어서는 안 될 필수적인 성분을 가진다. 문장처리에 있어서 동사의 역할이 중요한 만큼 동사와 문장처리에 관한 연구는 영어권에서 오래도록 진행되 고 있다. 동사는 주어, 목적어 혹은 보어 등과 같이 문장의 구성요 소들 사이의 관계를 드러내는 역할을 하게 되는데, 이때 동사가 드 러내는 관계의 대상을 논항(argument)이라고 하고, 이 논항의 역할 을 의미역(thematic role)이라고 한다(Kim \& Woo, 2007). 그리고 동사의 정보가 각 구성 성분들의 의미역을 결정하는 과정을 의미 역 처리라고 한다(Carlson \& Tanenhaus, 1988; Rayner, Carlson, \& Frazier, 1983). 동사에 의한 의미역 처리의 중요성은 여러 연구자들 에 의해 제기되었는데, 특히 Frazier (1987)는 의미역 처리는 문장이 해에서 커다란 역할을 한다고 주장한다. 명사에 비해 동사 처리 과 제는 좀 더 어려운 단계로 분류되며, 동시에 더욱 복잡한 처리 과정 을 필요로 함을 알 수 있다(Kim, 2017). 실어증 및 치매와 같은 신경 언어장애 환자들뿐만 아니라 정상 노년층의 경우에도 명사 처리보 다 동사에서 수행력과 정확성이 더 낮은 것으로 보고된다(Almor et al., 2009; Mätzig, Druks, Masterson, \& Vigliocco, 2009).

동사 처리 및 동사 활용 예측 능력이 노화와 함께 감소된다는 것 은 여러 연구에 의해 보고되었다(Bryan, Luszcz, \& Crawford, 1997; Howard, 1983). 하지만 이는 주어-동사-목적어(Subject-Verb-Object, SVO)어순을 사용하는 동사 활용 예측 매커니즘에 친숙한 영 어권 연구결과가 대다수이다. 영어권에서는 SVO의 기본 어순을 갖 고, 동사는 뒤에 나오는 명사에 대한 의미적 예측을 가능하게 해 주 는 역할을 하는 중요한 문장구성 성분이다(McRae, Ferretti, \& Amyote, 1997). 동사의 구문구조 내 위치는 이후에 나올 명사구에 대 한 기대를 형성한다는 측면에서 구문분석에 미치는 영향이 크다 (Kim, 2001). Brouwer, Özkan과 Küntay (2019)는 SVO어순에 보다 친숙한 네덜란드어 사용자와 주어-목적어-동사(Subject-ObjectVerb, SOV) 어순을 사용하는 터키어 사용자 간 동사 기반 명사 예 측 능력에 차이가 있을 것이라 가정하고 4-5살 아동과 성인을 대상 으로 하여 연구를 진행하였다. 실험 문장은 의미적 제한성을 가진 조건의 '소년이 큰 케이크를 먹는다(The boy eats the big cake)'와 중 립적 조건의 '소년이 큰 케이크를 본다(The boy sees the big cake)' 가 사용되었고, 실험 문장은 주어-동사-목적어 순서로 제시되었다. 연구 결과, SVO어순에 보다 익숙한 네덜란드어 사용자들은 예상 했던 대로 케이크(cake)와 나무(tree) 중 명사 '케이크'를 예측하는 정도가 '보다(see)' 동사를 들었을 때보다 '케이크'와 의미적으로 높
은 연관성을 가진 '먹다(eat)' 동사를 들었을 때 더욱 높았다. SOV어 순을 가진 터키어 사용자들 또한 제시된 동사를 듣고 난 후, 예측 정도가 높은 조건에서 다음에 제시될 명사구에 대한 높은 예측 정 도를 보여주었다. 이는 터키어 사용자들이 어순에 비교적 자유롭 기 때문이며 동사가 가장 마지막에 위치하는 어순을 가진 언어 사 용자들도 문장처리 시 동사 기반 예측 처리를 하고 있음을 알 수 있 다고 결론 맺었다. 연구를 통해 동사 정보를 활용해 명사구를 예측 하는 능력이 SVO어순에 보다 친숙한 네덜란드어 사용자와 SOV어 순의 터키어 사용자 간 차이가 없다는 것을 입증했다. 이는 SOV어 순의 언어 사용자가 SVO어순에 보다 익숙한 언어 사용자에 비해 동사 정보를 활용하는 능력이 떨어질 것이라는 가설을 반증하는 연구이다.

$\mathrm{SVO}$ 어순을 사용하는 영어 사용자들이 동사 정보를 사용하여 뒤따라오는 명사구의 의미역을 예측하는 것은 놀라운 일이 아니다 (Brouwer et al., 2019). 하지만 영어 사용자와 달리 SOV어순을 사 용하는 한국어 사용자의 경우에도 동사를 활용하여 관련된 의미 역 명사를 예측하는 처리 과정이 일어나는지 살펴보는 것은 동사 의 기능에 대해 더 깊이 살펴볼 수 있는 기회가 된다. 동사 후치어인 한국어를 사용하는 청년층과 노년층의 동사 활용 의미역 예측 처 리에 대한 연구는 동사의 기능에 대해 더 깊이 살펴볼 수 있는 기회 일 뿐 아니라 노화에 따른 동사 처리 및 의미역 예측의 변화에 대해 서도 살펴볼 수 있기에 의의가 있다.

노화가 노인의 언어장애를 초래한다는 것은 일반적으로 알려진 내용이지만, 노화에 따른 실시간 언어처리능력 손상 여부에 대해서 는 아직 연구가 부족한 실정이다(Silagi, Rabelo, Schochat, \& Mansur, 2015). 많은 선행연구들은 동사 관련 과제를 진행했을 때 청년 층이 노년층에 비해 더 높은 수행을 보인다고 주장한다(Hultsch, Hertzog, Small, McDonald-Miszczak, \& Dixon, 1992; Salthouse, 1996). 반면 동사 과제에서 노년층과 청년층 간 차이가 없다는 연구 도 있어(Mittenberg, Seidenberg, O'Leary, \& DiGiulio, 1989) 여전 히 논쟁이 많은 연구주제이다. 국외에서는 노화와 동사 처리와의 관련성에 대한 다양한 연구가 진행되고 있다(Almor et al., 2009; Mätzig et al., 2009). 반면 국내의 경우, 노년층을 대상으로 한 연구 는 뇌졸증이나 퇴행성 질환 대상자를 중심으로 이루어지고 있고 (Kim, Kim, Namkoong, Kim, \& Kim, 2006; Kim \& Kim, 2009; Oh, Eom, Park, \& Sung, 2016; Woo \& Kim, 2015), 정상 노년층을 대상으로 한 연구는 많지 않다. 정상 노년층을 대상으로 한 국내 연 구들을 살펴보더라도 이름대기나 단어 정의와 같은 표현 능력과 관 련한 연구는 비교적 활발하게 이루어지고 있으나(Lee, Lee, \& Lee, 2016; Kim, 2017) 동사 처리에 관련한 연구뿐 아니라 동사 기반 의 
미역 예측에 관한 연구는 상당히 제한적이다.

Burke와 MacKay (1997)는 연령의 차이에서 오는 복잡한 언어처 리나 문장 이해에 관련한 연구들을 진행한 결과, 노화에 따른 문장 이해 및 연령 관련 변화로 인한 언어처리에 대한 연구는 이해한 내 용을 부호화(encoding)하거나 회상(recall)하는 방법을 사용하는 것 보다 실시간 처리를 볼 수 있는 시선추적기를 통해 알아 볼 필요 가 있다고 주장한다. Federmeier, Kutas와 Schul (2010)은 동사를 포함한 언어 기반의 시선움직임(eye-tracking) 연구는 언어적 처리 뿐 아니라 시각적 처리를 하는 과정을 반영하고, 언어적 및 시각적 입력 모두에서 파생된 정보를 결합하고 지속적으로 업데이트되는 과정을 반영한다고 주장했다. 시선추적연구는 문장을 읽고 처리하 는 과정에서 독자의 눈동자 움직임을 측정 및 분석함으로써, 인간 의 사고 과정 및 활동을 살펴보려는 데 목적이 있다. 인간의 의미 처 리나 사고 과정은 눈동자 움직임에 고스란히 반영되고(Kim, 2015), 눈동자 움직임은 인지 과정을 외현적으로 드러낼 수 있는 표상이기 에(Han et al., 2012) 인지 처리 과정을 살펴보기 위한 연구에서 시 선추적방법이 사용된다. 시선추적연구를 통해 인지 처리 과정을 밀리세컨드 $(\mathrm{ms})$ 단위로 추출할 수 있기 때문에 단순한 회상이나부 호화 과제를 통한 방법보다 세부적인 정보를 얻을 수 있다. 시선고 정이 발생하는 이유는 정보처리를 위하여 시각적인 정보를 입력받 기 때문이며 시선고정 시간이 길어질수록 처리해야 할 정보의 양 이 많다는 것을 의미한다. 시선추적기법(eye-tracking method)은 언어처리 과정 중에 이루어지는 실시간 예측과정을 측정하는 데 빈번하게 사용되는 연구 방법이고, 언어처리 과정에 대한 객관적이 고 정량적인 정보를 제공해 준다(Cooper, 1974). Altmann과 Kamide (1999)는 구어가 나오기 전에 예측되는 명사구의 의미역으로 빈번한 안구 움직임이 일어나는 것을 예측 안구 운동(anticipatory eye movements)이라고 명명했다. 이들은 동사 기반 시선추적연구 를 통해 동사가 지닌 의미적 정보가 다가올 대상을 예측하는 데 사 용된다는 증거를 제공했다. Altmann과 Kamide (1999)의 연구를 주축으로 하여 이후 관련 연구들이 많이 진행되었다. Mani와 Huettig (2012)도 시선추적연구를 통해 아동도 친숙한 동사 뒤에 나올 의미적으로 어울리는 단어를 예측한다는 사실을 발견했다. 이를 통해 언어를 듣고 이해하기 시작하는 어린 아동기에서부터 동 사 기반의 예측이 가능하다는 것을 알 수 있다. 하지만 시선추적연 구가 국외에서는 활발히 진행되는 데 반해, 국내에서의 연구는 극 히 제한적이다. 따라서 본 연구는 한국어 사용 청년층과 노년층을 대상으로 시선추적기를 활용하여 동사를 기반으로 한 동사의 의미 역 예측 능력에 대해 알아보고자 한다.

즉, 동사-명사의 기능적 연관성을 바탕으로 하여 동사의 의미역
예측 정도(고 vs. 저)에 따른 집단 간(청년층 vs. 노년층) 의미역 예측 처리 능력을 시선추적기를 활용하여 비교해 봄으로써 노화에 따 른 동사 활용 예측 능력에 변화가 있는지 알아보고자 하였다.

연구 질문은 다음과 같다.

첫째, 동사의 의미역 예측 정도(고 vs. 저)에 따라 의미역 선택 반 응시간(response time, RT)에서 집단(청년층 vs. 노년층) 간 차이가 유의한가?

둘째, 동사의 의미역 예측 정도(고 vs. 저)에 따라 의미역 시선고 정비율(proportion of target fixations)에서 집단(청년층 vs. 노년층) 간 차이가 유의한가?

\section{연구방법}

\section{연구대상}

본 연구는 청년층 20 명(남 4 명, 여 16 명), 노년층 20 명(남 5명, 여 15 명), 총 40 명이 참여하였다. 집단 간 교육년수의 평균을 맞추었고, 통계적으로 유의한 차이가 없었다. 실험은 이화여자대학교 연구윤 리위원회의 IRB 승인을 받아 진행하였다(IRB No. 165-7). 모든 대 상자는 실험 참가 전에 실험 참여 동의서에 서명 후 실험을 진행하 였다. 모든 대상자에게 연구의 목적, 실험 내용, 소요 시간, 절차 등 에 대한 안내를 진행하였고, 두 집단 대상자 선정 기준은 다음과 같 다. (1) 건강선별기준(Christensen, Multhaup, Nordstrom, \& Voss, 1991)에 근거하여 신경학적 또는 정신적인 병력이나 두뇌손상 병력 이 보고되지 않았으며, (2) 언어 및 인지적 신경학적 손상, 발달적 병 력이 보고되지 않았으며, (3) 한국판 간이정신상태검사(KoreanMini Mental State Examination, K-MMSE; Kang, Na, \& Hahn, 1997 ) 점수가 연령 및 교육년수에 비해 $16 \%$ ile 이상으로 정상 범위 에 해당하며(Kang, 2006), (4) 교육년수가 9년 이상이며, (5) 자가보 고 및 선별검사 과정을 통해 과제를 수행하는 데 필요한 시각 및 청 각 능력에 문제가 없음이 확인되었고, (6) 폐쇄공포증이 없으며, (7) 한국어가 모국어인 자이다. 노년층은 추가적으로 서울신경심리검

Table 1. Demographic information on participants

\begin{tabular}{lcc}
\hline & Young group $(\mathrm{N}=20)$ & Old group $(\mathrm{N}=20)$ \\
\hline Gender & & \\
Male & 4 & 5 \\
Female & 16 & 15 \\
Age (yr) & $23.84(2.56)$ & $66.00(2.70)$ \\
Education (yr) & $12.84(1.64)$ & $13.22(2.32)$ \\
K-MMSE & $29.50(0.76)$ & $28.10(1.24)$ \\
\hline
\end{tabular}

Values are presented as mean (SD).

K-MMSE = Korean-Mini Mental State Examination (Kang, Na, \& Hahn, 1997). 
사 2판(Seoul Neuropsychologic Screening Battery-II, SNSB-II; Kang, Jang, \& Na, 2012)을 진행하였으며, SNSB-II의 하위검사인 서울구어학습검사(Seoul Verbal Learning Test, SVLT) 점수가 연 령 및 교육년수에 비해 $16 \%$ ile 이상을 정상 범위로 간주하여 노년 층 대상자로 선정하였다. 본 연구에 참여한 연령 집단별 대상자 정 보는 Table 1에 제시하였다.

\section{연구과제}

실험자극

연구과제는 동사의 의미역 예측 정도(고 vs. 저)가 동사의 의미역 예측에 미치는 영향을 살펴보기 위해 자체적으로 제작하였다. 제 작 전, 어휘의 사용빈도를 조사하였다. Marinellie와 Chan (2006) 은 여러 요인 중 어휘 사용빈도가 어휘 산출과 크게 관련 있다고 주 장하며 여러 연구들을 제시했다. 즉, 사용빈도가 높을수록 어휘 산 출이 쉽다는 것이다(Eimas, Marcovitz-Hornstein, \& Payton, 1990; Jusczyk \& Aslin, 1995).

이에 본 논문에서 청각적으로 제시될 동사와 시각적으로 제시될 명사는 Seo (2014)를 참고하여 한국어 동사 빈도수, 명사 빈도수에 수록된 어휘를 빈도수별로 정리하였고, 그중 의미가 적절한 동사와 명사로 선정하였다. 우리나라에서는 광범위한 친밀도 기초 연구가 많이 이루어져 있지 않은 관계(Jeong, Lee, \& Seo, 2007)로 실험에 서 사용할 기초 어휘에 대해 22 명의 성인을 대상으로 선별검사를 진행하였다. 선별검사는 실험에서 사용할 동사와 명사를 바탕으로 각 개인이 지각하는 동사와 명사의 연관성 및 친밀도를 조사하였 고, 최종 어휘를 선별하고 수정했다.

청각적 제시 과제로 사용된 문장은 Hintz 등(2017)에서 사용된 'the man peels at this moment an apple' 구조를 참고하여 '철수가 깎다 지금 사과-(주어-동사-목적어 순)'의 형식으로 제시되었다. 동 사를 듣고 난 후, 이후에 올수 있다고 예측되는 가장 적절한 의미역
(명사) 사진을 고르는 과제이다. 선행논문의 실험에서 동사와 목표 명사 사이에 “패딩”(at the moment)이라 불리는 부사구를 넣어 참 여자들이 동사를 듣고 난 후 예측 및 반응 시선 움직임을 할 수 있 는 시간을 제공한 것처럼 본 연구에서도 동사 다음에 “지금” 이라 는 부사를 넣어 의미역(theme)을 예측할 수 있는 시간을 제공했다. 실험 과제는 예측 정도 고, 저 조건으로 이루어져 있고, 이때 예측 정도 '고' 조건은 동사를 들었을 때 목표 의미역을 예측하기 쉬운 조 건을 의미하는 것이다. 동사와 특정 목표 의미역 간에 의미적 연관 성이 큰 경우로 '깎다-사과'를 예로 들 수 있다. 예측 정도 '고' 조건 에서는 목표 의미역이 아닌 나머지 3 개의 의미역은 동사와 의미적 으로 어울리지 않아야 한다. 반면, 예측 정도 '저' 조건은 동사와 4 개의 의미역 모두가 의미적 연관성이 있어서 목표 의미역을 예측하 기 어려운 경우이다. '사과-그리다'처럼 '그리다' 동사만으로 '사과' 를 예측하기 어려움을 알 수 있다. 구체적인 실험 문장과 함께 제시 되는 그림자극에 대한 예시는 Table 2와 같다.

\section{실험자극 배열}

시각적 자극은 글자가 아닌 그림자극으로 제시되었다. 문항당 2 $\times 2$ 배열로 4 개의 단어가 동시에 제시되어야 하는데 글자로 제시 할 경우 같은 음절수로의 통합(예: 4 개 단어 모두 2 음절 단어 또는 3 음절 단어)문제로 단어 선택에 제한이 생길 것을 고려해 글자가 아 닌 그림으로 제공했다. 실험 문항에서 각 목표자극과 함께 제공되 는 방해자극으로 사용될 어휘는 선행연구인 Hintz 등(2017)에서 제시한 자극을 바탕으로 하여 선정하였고, 한국어에서 사용하기 어려운 명사는 한국어 고빈도 어휘 사전을 활용하여 변경하였다.

방해자극 선정 시, 예측 정도가 높은 조건에서는 3 개의 방해자 극은 동사와 어울리지 않는 것으로 선정하였고, 예측 정도가 낮은 조건에서는 3 개의 방해자극 모두 동사와 어울릴 수 있어야 하는 점 을 중점으로 하여 선택하였다. 예를 들어, 동사 '깎다'와 함께 제시

Table 2. Experimental stimuli for each condition

\begin{tabular}{ll}
\hline Degree of prediction & Auditory stimulus \\
\hline High & The man peels at this moment an apple \\
Low & The man draws at this moment an apple
\end{tabular}


될 방해자극 3 개(개미, 선풍기, 컵)는 동사와 의미적으로 어울릴 수 없어야 하고, 예측 정도가 낮은 조건에서 제시되는 동사 '그리다'와 는 모두 의미적으로 가능한 것이어야 하는 것이다. 방해자극을 포 함한 4 개의 의미역과 동사는 선정한 후에 한국어 사용자들을 대상 으로 구글 서베이를 통해 확인 절차를 거쳤다.

그림우월효과(picture superiority effect)에 따르면 그림으로 제 시될 때 관련된 정보에 접근하는 것이 더 쉽고, 단어보다 더 잘 회상 된다는 것을 반복적으로 보여주었다(Nelson, Reed, \& Walling, 1976). 또한 시선 움직임의 색깔 효과(color effect)를 배제하기 위해 시각적 제시물인 사진은 흑백으로 통일하였다.

\section{연구도구}

시선추적기는 적외선 조명과 컴퓨터 기반의 이미지 프로세싱을 사용해 안구의 위치와 움직임을 실시간으로 추적하여 인지 과정을 확인할 수 있는 기기이다. 본 연구에서는 동사의 예측 정도에 따른 의미역 처리를 살펴보기 위해 독일 Senso Motoric Instruments (SMI) 사의 'Experiment 3.1' 프로그램을 이용하여 실험을 설계하였고, $\mathrm{iView} \mathrm{X} \mathrm{RED} \mathrm{장비를} \mathrm{사용하여} \mathrm{측정하였다.} \mathrm{이후} \mathrm{시선추적기를} \mathrm{통}$ 해 측정된 시선움직임 처리 과정은 소프트웨어 'BeGaze 3.5'를 활 용해 분석하였다.

모든 음성자극은 소음이 통제된 방에서 성인 여성의 목소리로 녹음되었다. 녹음은 컴퓨터에 마이크를 연결하고 마이크와 입의 간 격을 $10 \mathrm{~cm}$ 두고 억양 및 속도를 동일하게 유지하며 진행되었다. 녹 음된 음원은 Praat 프로그램을 사용하여 각 어절 사이의 쉼을 동일 하게 맞추어 문장의 길이를 음절당 동일하도록 맞추었다. 각 문장 은 각 어절마다 $2,000 \mathrm{~ms}$ 로 맞추어 제시하였고, 목표 의미역은 모 든 문장에서 동일하게 $6,000 \mathrm{~ms}$ 가 되는 시점에 제시되었다.

실험자극은 Eye tracking solution 프로그램의 Experiment center 3.7을 실행하여 배열하였다. 또한, 실험이 진행됨에 따라 대상자 가 실험을 예측함으로써 연구결과가 왜곡될 수도 있기 때문에 매 꿈질 자극(filler stimuli)을 본 실험 문항 사이에 넣었는데 목표문 장과 다른 형태의 3 어절 문장으로 구성되었다. 자극의 제시 시 순서 효과(order effect)가 발생할 가능성이 있어 이를 배제하기 위해, 그 림 보기에서 목표그림이 한 위치에서 2회 이상 연속적으로 제시되 지 않도록 하였다. 또한 선행논문의 실험 설계와 같은 방법으로 2 개 의 리스트를 만들어 대상자별로 랜덤하게 제공하였다. 이에 각 집 단별로 10 명은 리스트 $\mathrm{A}, 10$ 명은 리스트 B를 진행하였다.

\section{연구 절차}

모든 대상자에게 개별적으로 인지 및 언어선별검사를 실시한 후
본 실험을 실시하였다. 본 연구의 모든 실험은 소음을 제거하기 위 해 독립된 실드룸에서 실시하였다. 실험 순서는 '보정 및 검증-연습 문제-본 실험자극 제시-응답’ 단계로 진행하였다. 시선추적기(EyeTracker)가 부착된 컴퓨터 앞에 앉으면 검사자는 참여자에게 과제 에 대해서 설명해 주었다. 본 실험이 시작되기 전에 진행하는 '보정 (calibration) 및 검증(validation) 단계'는 대상자의 시선과 컴퓨터 화면을 시선추적의 허용 범위 내에 해당하도록 각도를 맞추는 과 정이다. 보정 및 검증 단계에서 대상자는 검은색 화면에 순차적으 로 나타나는 빨간색 9 개의 목표점을 눈으로 따라가도록 한다. 대상 자 모두 목표점의 주시 결과가 모두 동공의 최적의 편차 값인 $0.5^{\circ}$ 이하가 될 때까지 실시하였다(Holmqvist et al., 2011).

이후, 본 실험에 앞서 대상자가 실험 내용을 숙지할 수 있도록 검 사자의 개인용 노트북으로 제작된 실험 안내사항을 통해 절차에 대해 안내하였다. 연구자는 대상자가 실험 참여 태도를 살피며 연 습문제를 푸는 모습을 함께 지켜보았다. 연습문제 중 오반응을 보 이는 문항에 대해서는 즉시 피드백을 주었고, 대상자가 연습문항 을 통해 실험을 충분히 이해하였다고 판단이 된 이후에 본 실험을 진행하였다.

본 실험 문항은 예측 정도가 높은 동사 40 개 문항, 예측 정도가 낮 은 동사 40 개 문항으로 총 80 개 문항으로 구성됐다. 2 개의 리스트를 만들어 실험에 참여한 순서대로 1 차, 2 차 랜덤하게 제공되었고, 각 리스트마다 조건별로 20 개 문항씩 총 40 개 문항으로 이루어졌다. 각 대상자는 실험에 참여하는 동안 같은 목표그림은 보지 못했다.

실험이 시작되면 본 과제에 들어가기에 앞서 연습 문항을 통해 과제 진행방법에 대해 설명했다. 20 문장을 진행하고 나면 앞서 진 행했던 보정단계를 위해 빨간 점이 화면에 제시되는데 그때 휴식을 취하고 싶으면 5 분간 휴식 후 다음 문항들을 진행하도록 했다. 본 문항이 시작되면 '+' 표시가 화면 중앙에 $200 \mathrm{~ms}$ 동안 제시된 후, 음성자극 제시와 함께 화면에 그림이 제시된다. 문장은 “철수가 깎 다/그리다 지금 사과” 형식의 어절 형태로 제시되고 청각적 자극의 각 어절은 동일하게 $2,000 \mathrm{~ms}$ 간격으로 제시되었다. 문장이 시작한 후 2,000 ms부터 동사가 제시되고, 의미역(명사)을 예측할 수 있는 시간을 제공하기 위해 부사 ‘지금'이 제시된 후, 의미역이 제공되었 다. 각 어절의 시간은 한국어 사용 성인의 말속도가 평균 초당 2.77 음절임을 제시한 연구를 참고하여 어절마다 2초로 맞추어 제시하 였다(Kwon, Kim, Choi, Na, \& Lee, 1998). 대상자는 청각적으로 제 시된 언어정보를 들으며 4 가지 그림 자극을 보고 문장과 어울리는 그림을 선택하고 스페이스바를 눌러서 다음 문항으로 넘어가도록 한다. 이때 각 그림 위치와 일치하는 키보드(Q, I, Z, M)에 입체감 있는 스티커를 부착하여 선택이 쉽도록 하였다. 의미역이 제시되기 


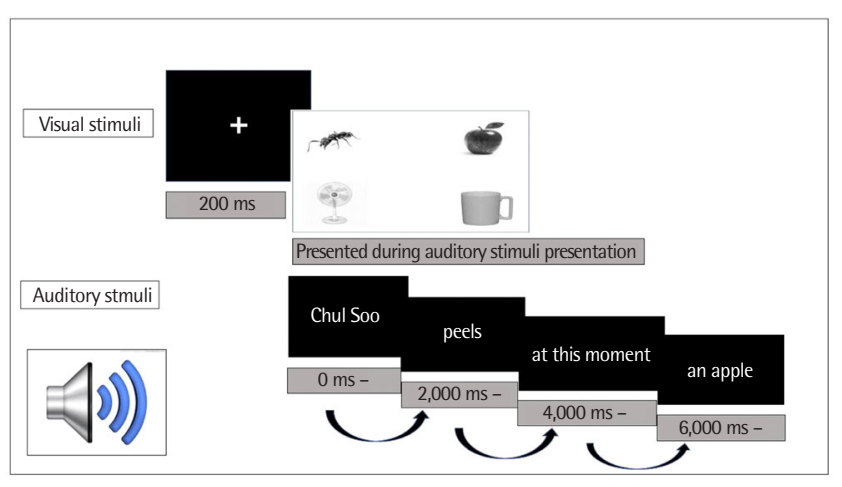

Figure 1. Experimental procedures.

전에 정답을 누르더라도 뒤에 제시되는 의미역을 확인하고 넘어가 도록 주의시켰다. 이후 실험이 진행되는 동안은 최대한 집중하여 참 여할 것을 당부하고, 본 실험을 진행하였다. 대상자는 연습 문항을 조건별 3 문항씩 총 6 문항을 진행한 뒤에 본 실험에 들어갔다. 각 실 험은 평균 10-15분 정도 진행되었다. 실험 순서도는 Figure 1과 같다.

\section{자료 분석}

반응시간(response time)

대상자가 어절별로 제시되는 문장을 듣는 동시에 화면에 제시된 4 개의 그림을 보는 동안 동사 다음에 나올 의미역(명사)에 대한 확 신이 들었을 때 최대한 빨리 해당 그림자극이 있는 위치의 키보드 를 눌러 선택할 수 있다. 미리 정답을 선택한 후에도 마지막에 제시 되는 의미역을 확인하고 다음 문제로 넘어가도록 하였다, 이때 키 보드를 누른 시간이 반응시간이다. 이때 방해자극을 먼저 선택했 더라도 그 시간이 아닌 목표 의미역을 정확하게 누른 시간을 반응 시간으로 분석하였다. 이는 BeGaze를 통해 밀리세컨드(1/1,000초) 단위로 자동 측정된다.

자료의 정확성을 위해 대상자의 데이터를 두 가지 조건별로 구분 한 후, 각 조건별 반응시간의 평균과 표준편차를 계산하였다. 이 중 에 $3 \mathrm{SD}$ 이상 되는 이상값(outlier)은 분석에서 제외하고자 확인하 였다. 이후 집단별로 전체 대상자의 반응시간에 대한 평균과 표준 편차를 계산한 후, $3 \mathrm{SD}$ 이상 되는 값은 이상값(outlier)으로 분석에 서 제외하는(DeDe, Caplan, Kemtes, \& Waters, 2004) 확인 절차를 진행했다. 이를 통해 청년층 중 1 명이 분석의 대상에서 제외되었다.

\section{시선고정비율(proportion of fixation)}

시선고정비율은 전체 그림을 본 시선고정시간 중 다른 그림자극 과 비교해 목표그림을 본 시간의 비율이다. 즉, 전체 시선고정 중 특 정 그림자극에 대한 시선고정이 얼만큼 일어났는가를 보고자 한
다. 따라서 화면에 제시된 4 개의 그림자극을 본 전체 시선고정시간 에서 하나의 목표 그림자극을 본 시선고정시간의 비율로 목표 의미 역에 대한 시선고정비율을 구하였다. 예를 들어 '철수가 지금 깎다 사과'의 문장에서는 '사과, 개미, 선풍기, 컵' 4 가지 그림을 본 전체 시선고정시간과 목표 그림자극인 '사과' 그림을 본 시선 고정 시간 의 비율을 본 것이다. 자료의 정확성을 위해 시선고정비율에 대해 서도 $3 \mathrm{SD}$ 이상 되는 이상값(outlier)은 분석에서 제외하는 확인 절 차를 진행하였다.

분석 자료를 추출할 때 SMI사의 분석 프로그램인 BaGaze3.7을 실행하여 Adjust event detection 기능에서 데이터 추출 변수(detection parameters)를 설정한 후, Metrix Export 기능을 실행하여 시선추적 데이터를 추출하였다. 시선고정의 추출값은 오른쪽 눈 기 준으로 최소값을 $100 \mathrm{~ms}$ 로 지정하였다. 시선추적 데이터 분석의 관심영역(areas of interst, $\mathrm{AOIs}$ )은 각 과제 화면에서 제시되는 목표 자극 그림과 방해자극 그림이다. 자극이 제시되는 모니터(19 inch, resolution $1,680 \times 1,050$ pixel)에서 모든 그림의 AOIs 크기는 가로 $30 \%$, 세로 $20 \%$ 의 비율로 동일하게 제시되었다.

동사의 의미역 예측정도 고, 저에 따른 청년층과 노년층의 실시 간 예측 및 처리능력을 보기 위하여 동사가 제시되기 $500 \mathrm{~ms}$ 전부 터 의미역이 제시된 후 $500 \mathrm{~ms}$ 인 구간을 추출 구간으로 설정하고 추출하였다. 분석 구간 설정은 선행연구인 Hintz 등(2017)의 연구 설계방법과 동일하게 진행하였다.

본 연구에서 분석하고자 하는 의미역 시선고정비율은 전체 시선 고정시간에서 목표 의미역을 본 시선고정시간의 비율로 계산하였 다. 전체 그림자극 중 목표 그림자극을 본 시선고정비율을 구하기 위해서는 4 개 그림자극에 대한 시선고정시간을 알아야 한다. 이에 BaGaze3.7을 통해 추출한 데이터인 평균시선고정(average fixation) 과 시선고정횟수(fixation count)를 곱하여 각 그림자극에 대한 시 선고정시간을 도출하였다. 방식은 아래와같다.

시선고정시간(duration of fixation $)=$ 평균시선고정 $\times$ 시선고정횟수

평균시선고정은 시선고정이 일어난 모든 시간을 시선고정이 일 어난 횟수로 나눈 값을 의미한다. 즉, 한 번의 시선고정에서 평균적 으로 시선이 머무른 시간을 의미한다, 시선고정횟수는 $200 \mathrm{~ms}$ 이 상 시선이 머무른 횟수를 의미한다. 예를 들어, 시선고정이 (a)영역 에서 $300 \mathrm{~ms}$, (b)영역에서 $400 \mathrm{~ms}$, (c)영역에서 $200 \mathrm{~ms}$ 동안 발생했 다면 시선고정횟수는 3 회, 총 시선고정시간은 $900 \mathrm{~ms}$, 평균 시선고 정시간은 $300 \mathrm{~ms}$ 이다. 따라서 BeGaze를 통해 추출한 시선분석 요 소인 시선고정횟수와 평균시선고정을 곱하여 각 그림영역에 대한 시선고정시간을 구하였다. 그 이후, 각 그림을 응시한 전체 시선고 
정시간과 목표 그림자극을 본 시선고정시간의 비율로 의미역 시선 고정비율을 구했다. 방식은 아래와같다.

$$
\text { 의미역 시선고정비률 }=\frac{\text { 목표 의미역 시선고정시간 }}{\text { 전체시선고정시간 }} \times 100
$$

\section{통계적 처리}

의미역 예측 정도(고, 저)에 따라 집단 간 의미역 예측 반응시간, 시선고정비율에 유의한 차이가 있는지 알아보기 위해 이원혼합분 산분석(two-way mixed ANOVA)을 실시했다. 집단(노년층, 청년 층)은 집단 간 요인으로, 동사의 의미역 예측 정도(고, 저)는 집단 내 요인으로 분석은 SPSS version 20 (SPSS Inc., Chicago, IL, USA)을 사용하였다.

\section{타당도}

실험자극의 타당도를 알아보기 위해 실험에 참여하지 않는 22 명 (남자 12명, 여자 10명)을 대상으로 실험 문장에 사용될 동사와 명 사에 대한 대한 설문을 실시하였다. 설문지는 구글(Google) 드라이 브 내 설문지 만들기를 이용하였으며, 참여자들이 사이트에 접속 하여 설문지를 작성하고 자동으로 결과를 받았다. 설문 문장은 실 제 실험에 사용할 문장들로 선택하였고, 복수 선택이 가능하도록 설계하여 참여자들은 문장을 보고 빈칸에 들어갈 수 있는 단어를 하나 또는 가능하다고 생각하는 것 모두 선택하도록 안내되었다. 설문지 결과를 통해 예측 정도가 높은 조건의 문장에서는 해당 명 사가 $100 \%$ 로 나왔는지 확인하는 것을 목표로 하였고, 예측 정도가 낮은 조건의 문장에서는 4 가지 명사 모두 가능하다는 것을 확인하 였고, 선택되지 않은 명사는 수정을 하였다. 수정한 어휘에 대해서 는 성인 20 명을 대상으로 추가 설문을 실시하여 4 가지 명사 모두 가능함을 확인하였다.

\section{연구결과}

\section{동사의 의미역 예측 정도에 따른 집단 간 반응시간 분석}

예측 정도에 따른 집단 간 차이를 알아보기 위해 행동 데이터인 반응시간에 대해 개체 간 조건으로 집단(청년층, 노년층)을 설정하

Table 3. Descriptive statistics of response time ( $\mathrm{ms}$ ) for each predictability

\begin{tabular}{lccc}
\hline Predictability & Young group ( $=19)$ & Old group ( $=19)$ & Total \\
\hline High & $4,154.28(623.12)$ & $6,043.43(513.66)$ & $5,098.85(568.38)$ \\
Low & $6,412.02(221.62)$ & $6,877.87(249.57)$ & $6,644.94(235.59)$ \\
\hline
\end{tabular}

Values are presented as mean (SD).
고, 개체 내 조건으로 예측 정도(고, 저)를 설정하여 이원혼합분산 분석(two-way mixed ANOVA)을 실시하였다. 예측 정도에 따른 집 단 간 의미역 선택 반응시간에 대한 기술통계는 Table 3 과 같다.

예측정도에 따른주효과가 통계적으로 유의하였다 $\left(F_{(1,36)}=242.992\right.$, $p<.001)$. 예측정도가 높을 때 반응시간은 예측 정도가 낮을 때의 반응시간보다 유의하게 빠르게 나타났다. 집단에 따른 주효과도 통 계적으로 유의하였다 $\left(F_{(1,36)}=133.055, p<.001\right)$. 노년층의 반응시간 이 청년층의 반응시간보다 유의하게 높았다.

집단과 예측 정도에 대한 이원상호작용이 통계적으로 유의하였 다 $\left(F_{(1,36)}=51.481, p<.001\right)$. 즉, 예측 정도가 높은 과제에서 집단 간 차이가 예측정도가 낮은 과제에서의 집단 간 차이보다 더 큰 것으 로 나타났다. 예측 정도에 따른 반응시간 주효과 분산분석표는 $\mathrm{Ta}-$ ble 4 와 같다.

예측 정도가 낮은 과제일 때는 청년층과 노년층 모두 의미역 선 택이 의미역이 제시된 이후 이루어진 데 반해 예측 정도가 높은 과 제에서는 청년층, 노년층 모두 의미역이 제시되기 전에 선택이 이루 어졌다. 하지만 예측 정도가 높은 경우 청년층의 의미역 예측 반응 시간이 유의하게 빨라지는 데에 반해 노년층의 예측 반응시간은 청 년층에 비해 예측 정도의 고, 저에 따른 변화가 크지 않는 것에 기인 한다. 동사의 의미역 예측 정도와 집단에 대한 이차상호작용에 대 한 그래프는 Figure 2와 같다.

\section{동사의 의미역 예측 정도에 따른 집단 간 의미역 시선고정비율}

청년층과 노년층의 동사의 의미역 예측 정도 고, 저에 따른 의미 역 예측 반응시간에 대한 평균과 표준편차는 Table 5 와 같다.

집단 간주효과가 통계적으로 유의하였다 $\left(F_{(1,36)}=12.403, p<.001\right)$. 노년층의 의미역 시선고정비율이 예측정도 고, 저에 따른 두 조건 모두에서 청년층에 비해 유의하게 낮은 수치를 보였다. 예측 정도에 따른 주효과가 통계적으로 유의하였다 $\left(F_{(1,36)}=205.79, p<.001\right)$. 예 측 정도가 높은 과제에서의 의미역 시선고정비율이 예측 정도가 낮

Table 4. ANOVA results from response time (ms) for each predictability

\begin{tabular}{lcrcc}
\hline & Sum of squares & df & Mean square & $F$ \\
\hline Between factor & & & & \\
$\quad$ Group & 2.634 E7 & 1 & $2.634 E 7$ & $133.055^{* * *}$ \\
Error & $7,127,593.032$ & 36 & $197,988.695$ & - \\
Within factor & & & & \\
Predictability & $4.542 E 7$ & 1 & $4.542 E 7$ & $242.992^{* * *}$ \\
Predictability×Group & $9,622,361.980$ & 1 & $9,622,361.980$ & $51.481^{* * *}$ \\
Error & $6,728,732.184$ & 36 & $186,909.227$ & - \\
\hline
\end{tabular}

${ }^{* * *} p<.001$ 


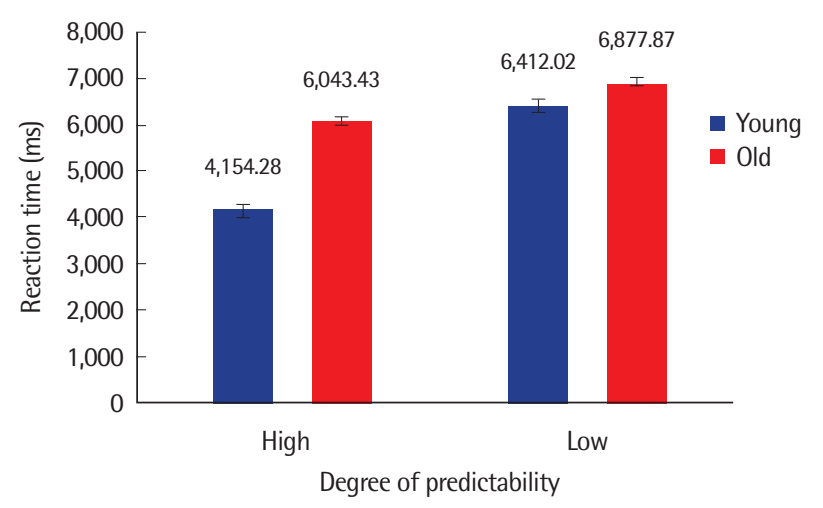

Figure 2. Response time of prediction for each condition in young and old groups.

Table 5. Descriptive statistics proportion of fixation on the target for each condition

\begin{tabular}{lccc}
\hline Predictability & Young group $(\mathrm{N}=19)$ & Old group $(\mathrm{N}=19)$ & Total \\
\hline High & $60.35(9.65)$ & $46.86(6.68)$ & $53.60(8.16)$ \\
Low & $31.70(5.30)$ & $31.13(8.73)$ & $31.41(7.01)$ \\
\hline
\end{tabular}

은 과제에서의 시선고정비율보다 유의하게 더 높은 수치를 보였다. 집단과 예측 정도에 대한 이원상호작용 분석결과 통계적으로 유의 하였다 $\left(F_{(1,36)}=17.426, p<.001\right)$. 예측 정도에 따른 의미역 시선고정 비율 주효과 분산분석표는 Table 6과 같다.

예측 정도가 높은 과제에서 노년층의 의미역 시선고정비율이 청 년층에 비해 유의하게 낮은 시선고정비율을 보였다. 예측정도가 높 은 과제에서 집단 간 차이가 예측정도가 낮은 과제에서 집단 간 차 이보다 유의하게 큰 것으로 나타났다. 동사의 의미역 예측 정도와 집단에 대한 시선고정비율 이차상호작용 그래프는 Figure 3 과 같다.

\section{논의 및 결론}

노화에 의한 언어처리 능력의 감퇴는 국내외를 막론하고 관심을 갖고 연구하는 분야이고, 관련 연구가 다양하게 진행되어 왔다. 본 연구는 문장 예측에 관여하는 여러 요소 중 가장 큰 영향을 주는 동사와 명사의 기능적 연관성을 바탕으로 한 기존 연구를 활용하 여 노년층과 청년층의 동사 활용 예측 실시간 처리 과정을 비교하 고자 하였다. 동사에 의한 의미역 예측 처리에 있어서의 집단 간 차 이를 살펴보기 위해 예측 정도 고, 저에 따른 의미역 예측 반응시간 과 의미역 시선고정비율을 분석하였다.

연구의 구체적인 연구 목표는 다음과 같다. (1) 동사의 의미역 예 측 정도에 따라 두 집단의 의미역 예측 반응시간에 차이가 있는지
Table 6. ANOVA results from proportion of fixation on the target for each predictability

\begin{tabular}{lrrrc}
\hline & Sum of squares & df & Mean square & $F$ \\
\hline Between factor & & & & \\
$\quad$ Group & 938.435 & 1 & 938.435 & $12.403^{* * *}$ \\
$\quad$ Error & $2,723.797$ & 36 & 75.661 & - \\
Within factor & & & & \\
Predictability & $9,357.745$ & 1 & $9,357.745$ & $205.794^{* * *}$ \\
Predictability× Group & 792.384 & 1 & 792.384 & $17.426^{* * *}$ \\
Error & $1,636.974$ & 36 & 45.471 & - \\
\hline
\end{tabular}

${ }^{* * *} p<.001$.

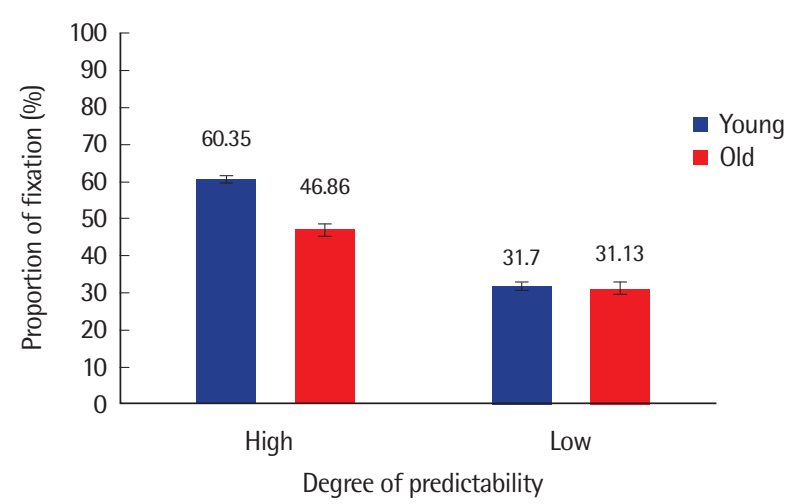

Figure 3. Proportion of target fixation for each condition in young and old groups.

알아봄으로써 SOV어순을 사용하는 한국어 사용자들도 동사를 활용한 예측 처리가 가능한지 알아보고자 하였다. (2) 동사의 의미 역 예측 정도에 따라 실시간 처리 능력에서 두 집단 간 차이가 있는 지 알아보고자 하였다. 즉, 반응시간과 시선고정비율을 봄으로 해 서 노화로 인해 동사 활용 예측 처리 과정에서의 감소가 진행되는 지 확인하고자 하였다. 연구 결과, 실시간 문장처리에서 의미역을 예측하는 동사 정보를 활용하는 능력이 노년층이 청년층에 비해 유의하게 감소되어 있음을 보였다. 의미역을 빠르게 예측할 수 있 는 동사들을 처리할 때 청년층은 그 정보를 더욱 빠르고 효율적으 로 활용하는 것으로 보인다. 예측 정도가 높은 과제에서 청년층과 노년층 모두 동사를 활용한 의미역 예측이 이루어짐을 확인할 수 있었지만 노년층의 예측 반응속도와 의미역 시선고정비율이 청년 층에 비해 유의하게 감소되어 있었다.

본 연구의 결과를 정리하면 다음과 같다. 첫째, 두 집단의 동사 활 용 의미역 선택 반응시간이 의미역 예측 정도의 고, 저에 따라 어떠 한 영향을 받는지 살펴보았다. 결과를 보면 집단 간 주효과와 예측 정도에 따른 주효과 모두 유의하게 나왔다. 청년층과 노년층 모두 의미역 선택 반응시간이 예측 정도가 높은 조건에 비해 예측 정도 
가 낮은 조건에서 유의하게 늦어지는 것으로 나왔고, 특히 노년층의 반응시간은 두 조건 모두에서 청년층에 비해 유의하게 늦어지는 것 으로 나타났다. 이 결과는 동사의 예측 정도에 따른 의미역 처리능 력이 노화에 따른 언어처리 속도의 감소와 밀접하게 관련됨을 시사 한다. 반응시간에 대한 이원분산분석 결과 집단 간 주효과와 예측 정도의 주효과 모두 유의한 차이를 보였다. 즉, 예측 정도가 높은 조 건에서 두 집단 모두 의미역이 제시되기 전에 의미역을 선택하는 경 향을 보였고, 청년층이 노년층에 비해 확실히 빠른 반응속도(RT) 를 보였다. 이에 반해 예측정도가 낮은 조건에서는 청년층과 노년층 모두 의미역을 듣고 난 이후에 해당 의미역을 선택하는 것으로 나 타났다.

둘째, 두 집단의 동사 활용 의미역 예측 및 반응 처리 동안의 의미 역 시선고정비율이 의미역 예측 정도의 고, 저에 따라 어떠한 영향 을 받는지 살펴보았다. 연구 결과, 집단 간 주효과와 예측 정도 고, 저에 따른 주효과 모두 유의하게 나왔다. 청년층과 노년층 모두 예 측 정도가 높을 때 의미역이 제시되기 전부터 의미역 시선고정비율 이 증가함을 볼 수 있다. 이는 두 집단 모두 동사를 활용한 의미역 예측 처리가 가능함을 보여주는 것이다. 단지, 노년층의 의미역 시 선고정비율은 청년층에 비해 유의하게 감소되어 있음이 나타났고, 예측 정도가 낮은 조건에서의 시선고정비율은 높은 조건에 비해 유 의하게 낮게 나타났다. 이를 통해 청년층이 노년층에 비해 동사를 활용한 예측을 더욱 빠르게 처리함을 알수 있다.

결과를 종합해 보면 SOV어순을 사용하는 한국어 사용자들도 동사 기반 명사구의 의미역 예측이 이루어짐을 확인할 수 있다. Hintz 등(2017)이 예측의 큰 요인이라 주장한 동사와 명사의 의미 적 연관성을 바탕으로 한 예측 정도 고, 저 조건에서의 의미역 예측 반응시간, 시선고정비율 모두에서 선행연구와 같은 차이를 보였다. Bryan 등(1997)은 청년층이 노년층에 비해 높은 수행력을 보인다 고 주장하였는데 본 연구결과를 통해서도 확인할 수 있었다. 노년 층은 청년층에 비해 의미역을 예측하는 동사 정보를 활용하는 실 시간 처리 능력에 감소가 있음을 보였다. 의미역을 의미적으로 강하 게 제한하는 동사들을 처리할 때 집단 간 차이가 크게 나타났으며 청년층은 동사 정보를 더 빠르고 효율적으로 활용하는 것으로 보 인다. 즉, 의미역을 의미적으로 제한하는 정도가 강한 동사를 처리 할 때 청년층이 노년층에 비해 그 정보를 빠르고 효율적으로 처리 하여 예측할 수 있는 것이다. 이를 통해 동사를 활용한 예측 능력은 노화와함께 감소되고 있음을 유추해 볼수 있고, 이는 기존의 결과 와 일치되는 연구결과이다(Almor et al., 2009; Bryan et al., 1997; Mätzig et al., 2009).

연구결과를 보면 의미역으로의 시선고정비율과 의미역 예측 반
응속도가 일치하는 결과를 보여주었는데 오프라인 측정 방식인 반 응시간과 실시간 처리 과정을 보여주는 시선고정비율 모두에서 노 년층이 전반적으로 낮은 수행력을 보였다. 이는 노화가 동사 활용 의미역 예측 처리능력의 감소에 영향을 준다는 것을 의미하고 본 연구에서 시사할 만한 점이다.

본 연구를 통해 동사의 의미적 네트워크를 활용한 의미역 예측 처리에서 정상 노년층과 청년층 간에 반응시간과 실시간 처리에서 의 차이가 있는지를 보았다. 연구결과를 살펴보면 선행연구 결과와 일치되게 예측 정도가 높은 조건에서 반응속도와 의미역 시선고정 비율 모두 큰 차이를 보였다. 노년층은 청년층과 비교했을 때 예측 에 있어서 느린 처리속도, 즉 양적인 측면에서의 차이를 보였다. 질 적인 측면에서도 의미를 통합하고 예측하는 과정에서 청년층에 비 해 효율적인 전략을 덜 사용하는 것으로 보이는데 이는 선행연구 에서 주장하는 제한된 처리자원과 관련된 것일 수 있다(Cohen, 1979).

노화에 따른 언어처리능력에 대해서 쉽게 정의 내리긴 힘들지만 노화에 의한 언어이해능력과 처리 속도에서의 감소를 주장하는 연 구가 있다(Howard, Shaw, \& Heisey, 1986). 본 연구결과에서도 인 지능력 측정에 대한 연령의 효과를 보여 주는 측정방법인 반응속 도에서 노년층이 청년층에 비해 유의하게 느린 속도를 보였고, 의미 역 예측 시선고정 처리에 있어서도 같은 결과를 보였다. 즉, 시선움 직임을 통한 실시간 처리 과정 연구를 통해 노년층이 청년층에 비 해 의미역을 예측하는 동사 정보를 활용하는 능력이 감소되어 있 음을 확인했을 뿐 아니라 의미역 예측 반응시간에서도 더 느린 속 도를 보였음을 확인했다. 이를 통해 의미역을 빠르게 예측해 줄 수 있는 동사들을 처리할 때 청년층이 그 정보를 더 빠르고 효율적으 로 활용하는 것을 알 수 있다. 오프라인 측정방식인 반응시간과 실 시간 처리의 결과가 전반적으로 같은 결과를 보인다는 점이 Hintz 등(2017)의 연구결과와 일치하고 눈 여겨 볼만하다.

동사의 처리 및 동사 활용 예측 능력이 노화와 함께 감소된다는 것은 여러 연구에 의해 보고되었지만, SVO어순을 사용하여 동사 활용 예측 매커니즘에 친숙한 영어권 연구결과가 대다수이다. Brouwer 등(2019)은 SOV의 어순을 가진 터키어와 SVO어순에 보다 익 숙한 네덜란드어 사용자를 대상으로 이들의 동사 기반 명사 예측 능력에 대한 연구를 진행했고, 연구결과 SOV어순을 사용하는 터 키어 사용자들도 네덜란드어 사용자 만큼이나 높은 예측 정도를 보여주었다. 한국어도 SOV어순을 사용하기 때문에 더욱 의미 있 게 볼 수 있는 연구이다. 그뿐만 아니라 Brouwer 등(2019)의 연구결 과와 같이 본 연구결과에서도 한국어 사용자들 또한 예측 정도가 높은 과제에서 동사 기반 의미역 예측 처리가 이루어짐을 확인할 
수 있었고, 처리 속도에 있어서 노년층이 청년층에 비해 감소되어 있음을 볼수 있었다. 또한 실시간 처리 과정을 살펴볼수 있는 시선 고정을 분석한 결과 노년층이 청년층에 비해 의미역 시선고정비율 이 유의하게 낮은 것을 확인할 수 있었다. 이는 노년층이 의미역을 예측하고 시선 고정한 시간이 청년층에 비해 더 적은 것을 의미한 다. 이 결과는 동사의 예측 정도에 따른 노년층의 의미역 예측 반응 속도와 시선고정비율 감소가 Salthouse (1996)가 연구를 통해 주장 한 노화에 따른 언어처리 속도의 감소와 밀접하게 관련됨을 시사 한다.

이러한 연구결과는 향후 동사 처리 과제뿐 아니라 노화에 따른 언어처리의 변화와 관련한 시선추적연구에 새로운 연구 주제 및 방 법을 제시해 줄 수 있을 것으로 보인다. 또한 시선추적을 활용하여 노화에 따른 언어처리 과정의 변화를 보는 것이 의미가 있음을 확 인할 수 있다. 더 나아가 실험에서 사용된 의미적 연관성이 높은 동 사와 명사의 쌍을 활용한 말뭉치 목록을 만들어 동사 처리와 이름 대기의 손상이 있는 치매 및 실어증 환자들의 치료 프로토콜에 활 용한다면 도움이 될 것으로 기대된다. 즉, 사과 깎다, 물/우유 마시 다, 책 읽다, 밥 먹다, 바지 입다, 문 열다, 라면 끓이다' 등의 의미적 연관성이 있는 명사와 동사를 함께 묶어서 치료로 활용한다면 명 사 어휘나 동사 어휘만을 활용하는 치료보다 더욱 효과적일 것으 로 본다.

연구의 제한점 및 후속연구를 위한 제언은 다음과 같다.

우선, 본 연구는 일반 청년층 20 명과 노년층 20 명으로 총 40 명의 대상자를 분석 대상자로 설정하였다. 이렇게 제한된 대상자의 수 를 통해서 얻은 연구의 결과를 일반화하는 것은 한계가 있으므로 후속연구에서는 연구결과를 일반화시키기 위해 각 집단별로 더 많 은 연구대상자를 확보할 필요가 있다.

다음으로 노년층 대상자를 모집할 때, 노년층의 평균 교육년수 를 청년층의 교육년수와 맞추다보니 모집하는 데 어려움이 있어서 남녀 성비를 맞추지 못했다. 연구결과에서는 연구에 참여한 남자 와 여자의 결과가 큰 차이를 보이지 않았지만 보다 정확한 연구를 위해서는 남녀성비를 맞추어 진행될 필요가 있을 것이다.

마지막으로 본 연구는 예측과 반응시간에 중심을 둔 연구일 뿐 아니라 의미역을 마지막에 제시해 주었기 때문에 정확도는 분석하 지 않았다. 하지만 Waters와 Caplan (2001)에 따르면 연령과 관련 한 언어처리 연구에서는 노화에 따라 언어처리 정확도의 감소가 나타난다고 하였다. 이에 후속연구에서는 예측정도가 높은 과제에 서는 의미역을 제시하지 않고 청년층과 노년층의 정확도를 확인하 면 더욱 흥미로운 연구가 될 것 같다.

\section{REFERENCES}

Almor, A., Aronoff, J. M., MacDonald, M. C., Gonnerman, L. M., Kempler, D., Hintiryan, H., ... \& Andersen, E. S. (2009). A common mechanism in verb and noun naming deficits in Alzheimer's patients. Brain and Language, 111(1), 8-19.

Altmann, G. T., \& Kamide, Y. (1999). Incremental interpretation at verbs: restricting the domain of subsequent reference. Cognition, 73(3), 247-264.

Brouwer, S., Özkan, D., \& Küntay, A. C. (2019). Verb-based prediction during language processing: the case of Dutch and Turkish. Journal of Child Language, 46(1), 80-97.

Bryan, J., Luszcz, M. A., \& Crawford, J. R. (1997). Verbal knowledge and speed of information processing as mediators of age differences in verbal fluency performance among older adults. Psychology and Aging, 12(3), 473-478.

Burke, D. M., \& MacKay, D. G. (1997). Memory, language, and ageing. Philosophical Transactions of the Royal Society of London. Series B: Biological Sciences, 352(1363), 1845-1856.

Carlson, G. N., \& Tanenhaus, M. K. (1988). Thematic roles and language comprehension. Syntax and Semantics, 21, 263-288.

Christensen, K. J., Multhaup, K. S., Nordstrom, S., \& Voss, K. (1991). A cognitive battery for dementia: development and measurement characteristics. Psychological Assessment: A Journal of Consulting and Clinical Psychology, 3(2), 168-174.

Cohen, G. (1979). Language comprehension in old age. Cognitive Psychology, 11(4), 412-429.

Cooper, R. M. (1974). The control of eye fixation by the meaning of spoken language: a new methodology for the real-time investigation of speech perception, memory, and language processing. Cognitive Psychology, 6(1), 84-107.

DeDe, G., Caplan, D., Kemtes, K., \& Waters, G. (2004). The relationship between age, verbal working memory, and language comprehension. Psychology and Aging, 19(4), 601-616.

Eimas, P. D., Marcovitz-Hornstein, S. B., \& Payton, P. (1990). Attention and the role of dual codes in phoneme monitoring. Journal of Memory and Language, 29(2), 160-180.

Federmeier, K. D., Kutas, M., \& Schul, R. (2010). Age-related and individual differences in the use of prediction during language comprehension. Brain and Language, 115(3), 149-161.

Frazier, L. (1987). Syntactic processing: evidence from Dutch. Natural Language \& Linguistic Theory, 5(4), 519-559. 
Han, C., Cheon, K., Kim, M., Park, Y., Lee, J., Choi, S., .. \& Jeong, M. (2012). Korean language education research methodology. Seoul: Pagijung.

Hintz, F., Meyer, A. S., \& Huettig, F. (2017). Predictors of verb-mediated anticipatory eye movements in the visual world. Journal of Experimental Psychology: Learning, Memory, and Cognition, 43(9), 1352-1374.

Holmqvist, K., Nyström, M., Andersson, R., Dewhurst, R., Jarodzka, H., \& Van de Weijer, J. (2011). Eye tracking: a comprehensive guide to methods and measures. Oxford, UK: Oxford University Press.

Howard, D. V. (1983). The effects of aging and degree of association on the semantic priming of lexical decisions. Experimental Aging Research, 9(3), 145-151.

Howard, D. V., Shaw, R. J., \& Heisey, J. G. (1986). Aging and the time course of semantic activation. Journal of Gerontology, 41(2), 195-203.

Hultsch, D. F., Hertzog, C., Small, B. J., McDonald-Miszczak, L., \& Dixon, R. A. (1992). Short-term longitudinal change in cognitive performance in later life. Psychology and Aging, 7(4), 571-584.

Jeong, H. J., Lee, O. B., \& Sehr, K. H. (2007). Korean naming test(verb) word list for adult: corpus-based basic vocabulary study. Journal of Speech \& Hearing Disorders, 16(2), 161-172.

Jusczyk, P. W., \& Aslin, R. N. (1995). Infants' detection of the sound patterns of words in fluent speech. Cognitive Psychology, 29(1), 1-23.

Kang, Y. (2006). A normative study of the Korean-Mini Mental State Examination (K-MMSE) in the elderly. Korean Journal of Psychology: General, 25(2), 1-12.

Kang, Y., Jang, S. M., \& Na, D. L. (2012). Seoul Neuropsychological Screening Battery (2nd ed.). Seoul: Human Brain Research \& Consulting.

Kang, Y., Na, D. L., \& Hahn, S. (1997). A validity study on the Korean MiniMental State Examination (K-MMSE) in dementia patients. Journal of the Korean Neurological Association, 15(2), 300-308.

Kim, H. (2015). Research for analysis of Korean reading process using eyetracking technology: for intermediate and advanced readers among foreign Korean learners. The Language and Culture, 11(2), 131-159.

Kim, J. W. (2017). Performances of verb naming according to the aging process in Korean normal adults. Journal of Speech-Language \& Hearing Disorders, 26(4), 11-19.

Kim, J., Kim, H., Namkoong, K., Kim, S., \& Kim, D. (2006). Spontaneous speech traits in patients with Alzheimer's disease. Korean Journal of Communication Disorders, 11(3), 82-98.

Kim, J. W., \& Kim, H. H. (2009). The characteristics of Korean morpheme production in Alzheimer's patients. Journal of Speech \& Hearing Research,
18(4), 75-90.

Kim, Y., \& Woo, J. (2007). The processing of thematic role information in Korean verbs. Korean Journal of Cognitive Science, 18(2), 91-112.

Kim, Y. J. (2001). Sentence processing and crosslinguistic variation: the case of Korean. Korean Journal of Cognitive and Biological Psychology, 13(4), 339-359.

Kwon, M., Kim, H., Choi, S. S., Na, D. L., \& Lee, K. H. (1998). A study for analyzing spontaneous speech of Korean adults with CIU scoring system. Korean Journal of Communication Disorders, 3(1), 35-49.

Lee, B. R., Lee, L., \& Lee, E. J. (2016). Semantic priming effect on the naming ability of young and elderly groups. Journal of Speech-Language \& Hearing Disorders, 25(4), 253-261.

Mani, N., \& Huettig, F. (2012). Prediction during language processing is a piece of cake-but only for skilled producers. Journal of Experimental Psychology: Human Perception and Performance, 38(4), 843-847.

Marinellie, S. A., \& Chan, Y. L. (2006). The effect of word frequency on noun and verb definitions: a developmental study. Journal of Speech, Language, and Hearing Research, 49(5), 1001-1021.

Mätzig, S., Druks, J., Masterson, J., \& Vigliocco, G. (2009). Noun and verb differences in picture naming: past studies and new evidence. Cortex, 45(6), 738-758.

McRae, K., Ferretti, T. R., \& Amyote, L. (1997). Thematic roles as verb-specific concepts. Language and Cognitive Processes, 12(2-3), 137-176.

Mittenberg, W., Seidenberg, M., O’leary, D. S., \& DiGiulio, D. V. (1989). Changes in cerebral functioning associated with normal aging. Journal of Clinical and Experimental Neuropsychology, 11(6), 918-932.

Nelson, D. L., Reed, V. S., \& Walling, J. R. (1976). Pictorial superiority effect. Journal of Experimental Psychology: Human Learning and Memory, 2(5), 523-528.

Oh, S. J., Eom, B., Park, C., \& Sung, J. E. (2016). Treatment efficacy of semantic feature analyses for persons with aphasia: evidence from meta-analyses. Communication Sciences \& Disorders, 21(2), 310-323.

Rayner, K., Carlson, M., \& Frazier, L. (1983). The interaction of syntax and semantics during sentence processing: eye movements in the analysis of semantically biased sentences. Journal of Verbal Learning and Verbal Behavior, 22(3), 358-374.

Salthouse, T. A. (1996). The processing-speed theory of adult age differences in cognition. Psychological Review, 103(3), 403-428.

Seo, S. (2014). Dictionary of the usage frequency of basic Korean vocabulary. Seoul: Hankookmunhwasa. 
Sang Heum Hwang, et al. • Aged-Related Differences in the Predictability of Verb-Thematic Roles

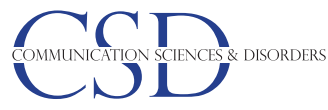

Silagi, M. L., Rabelo, C. M., Schochat, E., \& Mansur, L. L. (2015). Healthy aging and compensation of sentence comprehension auditory deficits. BioMed Research International, 2015, 640657.

Waters, G. S., \& Caplan, D. (2001). Age, working memory, and on-line syntactic processing in sentence comprehension. Psychology and Aging, 16(1),
128-144.

Woo, H. R., \& Kim, J. W. (2015). Different cognitive profiles between mild cognitive impairment and normal elderly depending on the type of attention and naming tasks. Journal of Rehabilitation Research, 19(2), 297-314. 


\title{
국문초록
}

\author{
시선추적을 활용한 동사의 의미역 예측 정도가 노년층 의미역 처리에 미치는 영향 \\ 황상흠 $\cdot$ 성지은 \\ ${ }^{1}$ 이화여자대학교 대학원 언어병리학과, ${ }^{2}$ 이화여자대학교 언어병리학과
}

배경 및 목적: 본 연구는 시선추적을 활용하여 동사의 의미역 예측 정도에 따른 집단 간 의미역 예측 처리능력을 비교함으로써 노화에 따른 한국인의 동사 활용 예측력의 변화에 대해 알아보고자 하였다. 방법: 실험 참여자는 청년층 20 명, 노년층 20 명, 총 40 명이다. 청각 자극과 그림자극은 동시에 제공되고, 동사를 들으며 예측되는 의미역(명사)을 선택하는 과제가 진행되었다. 문장은 주어-목적어-동사 (SOV)어순이 아닌 주어-동사-목적어(SVO) 순서로 제공되었고, 이 과제를 통해 SOV어순을 사용하는 한국어 사용자에게도 동사를 활 용한 예측 처리가 발생하는지, 노화에 의해 예측 능력의 저하를 보이는지를 살펴보았다. 실험을 통해 예측 반응시간과 의미역 시선고정 비율을 분석하였다. 결과: 노년층은 청년층에 비해 예측 반응시간과 목표 의미역 시선고정비율 모두 유의하게 감소된 것으로 나타났다. 특히, 예측 정도가 높은 과제에서 청년층의 의미역 예측 반응시간이 노년층에 비해 유의하게 빠른 반응시간을 보였고, 노년층은 예측 정도에 상관없이 예측 정도가 높은 조건에서도 의미역이 제시될 때까지 의미역 선택을 미루는 현상을 보였다. 논의 및 결론: 연구결과 를 통해 SOV어순을 사용하는 한국어 사용자들도 동사 활용 예측 처리가 이루어지는 것을 알 수 있음과 동시에 동사의 의미 네트워크 를 활성화하여 앞으로 제시될 명사를 예측하는 능력은 노화와 함께 감소되고 있음을 알 수 있다. 또한 시선추적기를 활용하여 실시간 처리 과정에서도 노년층이 동사 정보를 활용하는 능력에서 감소를 보이고 있음을 확인할 수 있음을 알 수 있다.

핵심어: 시선추적, 노화, 동사-명사 연관성, 동사 활용 예측 능력

본 논문은 2017년 대한민국 교육부와 한국연구재단의 지원을 받아 수행된 연구임(No. NRF-2017S1A2A2038375).

\section{참고문헌}

강연욱(2006). K-MMSE (Korean-Mini Mental State Examination)의 노인 규준 연구. 한국심리학회지: 일반, 25(2), 1-12.

강연욱, 나덕렬, 한승혜(1997). 치매환자들을 대상으로 한 K-MMSE의 타당도연구. 대한신경과학회지, 15(2), 300-308.

강연욱, 장승민, 나덕렬(2012). 서울신경심리검사 2판. 서울: 휴브알엔씨.

권미선, 김향희, 최상숙, 나덕렬, 이광호(1998). 한국 성인의 자발화 분석에 관한 연구: CIU 분석법을 중심으로. 언어청각장애연구, 3(1), 35-49.

김영진, 우정희(2007). 한국어 동사의 의미역정보 처리과정. 인지과학, 18(2), 91-112.

김정완(2017). 정상 성인의 노화과정에 따른 동사 이름대기 능력. 언어치료연구, 26(4), 11-19.

김정완, 김향희. (2009). 알츠하이머성 치매 환자의 한국어 형태소 산출 특성. 언어치료연구 18(4), 75-90.

김정완, 김향희, 남궁기, 김세주, 김덕용(2006). 알츠하이머형 치매환자의 발화특성. 언어청각장애연구, 11(3), 82-98.

김현진(2015). 시선추적 기법(Eye-tracking)을 활용한 한국어 읽기과정 분석 연구. 언어와문화, 11(2), 131-159.

서상규(2014). 한국어 기본어휘 의미빈도 사전. 서울: 한국문화사.

오세진, 엄보라, 박채원, 성지은(2016). 실어증 환자를 위한 의미자질 이름대기 중재 효과에 관한 메타 분석. Communication Sciences \& Disorders,

21(2), 310-323.

우희림, 김정완(2015). 주의력 및 이름대기 과제 유형에 따른 경도인지장애 노인의 수행 프로파일. 재활복지, 19(2), 297-314.

이보람, 이란, 이은주(2016). 청년층과 노년층의 이름대기에서 나타나는 의미점화효과. 언어치료연구, 25(4), 253-261.

정한진, 이옥분, 서경희(2007). 성인용 동사이름대기 평가 어휘 목록: 말뭉치를 기반으로 한 기초 어휘 연구. 언어치료연구, 16(2), 161-172.

\section{ORCID}

황상흠(https://orcid.org/0000-0003-2034-0443); 성지은(https://orcid.org/0000-0002-1734-0058) 